\title{
COGNITIVE LINGUISTICS
}

\section{EDITOR-IN-CHIEF}

John Newman

University of Alberta, Canada

Monash University, Clayton, Australia

\section{ASSOCIATE EDITORS}

Dagmar S. Divjak

University of Sheffield, UK

Martin Hilpert

Université de Neuchâtel, Switzerland

Laura A. Janda

University of Troms $\emptyset$, Norway

Zoltán Kövecses

Eötvös Loránd University, Budapest,

Hungary

Teenie Matlock

University of California, Merced, USA

John R. Taylor

University of Otago, Dunedin,

New Zealand

\section{REVIEW EDITOR}

Amanda Patten

University of Birmingham, UK

\section{EDITORIAL ASSISTANT}

Claudia Heinrich

E-mail: cogling@ualberta.ca

\section{DE GRUYTER}

MOUTON 


\section{EDITORIAL BOARD}

Antonio Barcelona

University of Cordoba, Spain

Paul Chilton

Lancaster University, UK

William Croft

University of New Mexico at

Albuquerque, USA

Ewa Dabrowska

Northumbria University, UK

Holger Diessel

University of Jena, Germany

Ad Foolen

Radboud University, The Netherlands

Dirk Geeraerts

University of Leuven, Belgium

Raymond W. Gibbs

University of California at Santa Cruz, USA

Stefan Th. Gries

University of California at

Santa Barbara, USA

Tuomas Huumo

University of Turku, Finland

Iraide Ibarretxe Antuñano

University of Zaragoza, Spain

Seizi Iwata

Kansai University, Japan

Vsevolod Kapatsinski

University of Oregon, USA
Ronald W. Langacker

University of California at San Diego, USA

Jeannette Littlemore

University of Birmingham,

United Kingdom

Francisco J. Ruiz de Mendoza Ibáñez

Universidad de La Rioja, Spain

Klaus-Uwe Panther

University of Hamburg, Germany

Fey Parrill

Case Western Reserve University, USA

Frank Polzenhagen

University of Heidelberg, Germany

Sally Rice

University of Alberta, Canada

Hans Joerg Schmid

Ludwig-Maximilians-University,

Munich, Germany

Dan I. Slobin

University of California, Berkeley, USA

Elizabeth Closs Traugott

Stanford University, USA

Javier Valenzuela

University of Murcia, Spain

Arie Verhagen

Leiden University, The Netherlands

Jörg Zinken

University of Portsmouth, UK

Jordan Zlatev

Lund University, Sweden 
ABSTRACTED/INDEXED IN Baidu Scholar · Cabell's Directory · Celdes · Clarivate Analytics (formerly Thomson Reuters): Arts \& Humanities Citation Index; Current Contents/Arts \& Humanities; Current Contents/Social and Behavioral Sciences; Journal Citation Reports/Social Sciences Edition; Social Sciences Citation Index · CNKI Scholar (China National Knowledge Infrastructure) · CNPIEC · De Gruyter: IBR (International Bibliography of Reviews of Scholarly Literature in the Humanities and Social Sciences); IBZ (International Bibliography of Periodical Literature in the Humanities and Social Sciences) - EBSCO (relevant databases) · EBSCO Discovery Service · Elsevier: SCOPUS · ERIH PLUS (European Reference Index for the Humanities and Social Sciences) · Gale/Cengage · Genamics JournalSeek · Google Scholar · J-Gate · JournalTOCs · KESLI-NDSL (Korean National Discovery for Science Leaders) · Linguistic Bibliography Online · Linguistics Abstracts Online · Microsoft Academic · MLA International Bibliography · Naviga (Softweco) · Philosophy Documentation Center: Philosophy Research Index · PhilPapers · Primo Central (ExLibris) · ProQuest (relevant databases) . PsycINFO - ReadCube $\cdot$ ResearchGate $\cdot$ SCImago (SJR) - Sherpa/RoMEO · Summon (Serials Solutions/ProQuest) - TDNet · UB Frankfurt: BLL Bibliographie Linguistischer Literatur; OLC Linguistik · Ulrich's Periodicals Directory/ulrichsweb · WanFang Data · WorldCat (OCLC)

The publisher, together with the authors and editors, has taken great pains to ensure that all information presented in this work reflects the standard of knowledge at the time of publication. Despite careful manuscript preparation and proof correction, errors can nevertheless occur. Authors, editors and publisher disclaim all responsibility for any errors or omissions or liability for the results obtained from use of the information, or parts thereof, contained in this work.

ISSN 0936-5907 · e-ISSN 1613-3641

All information regarding notes for contributors, subscriptions, Open access, back volumes and orders is available online at www.degruyter.com/view/j/cogl

RESPONSIBLE EDITOR John Newman, Department of Linguistics, Faculty of Arts, 4-36A Assiniboia Hall, University of Alberta, Edmonton T6G 2E7, Canada. Email: cogling@ualberta.ca

JOURNAL MANAGER Sofie Schenkel, De Gruyter, Genthiner Straße 13, 10785 Berlin, Germany, Tel.: +49 (0)30 26005 - 381, Fax: +49 (0)30 26005 - 250.

Email: sofie.schenkel@degruyter.com

RESPONSIBLE FOR ADVERTISEMENTS Claudia Neumann, De Gruyter, Genthiner Straße 13, 10785 Berlin, Germany, Tel.: +49 (0)30 26005 - 226, Fax: +49 (0)30 26005 - 264,

Email: anzeigen@ degruyter.com

(C) 2018 Walter de Gruyter GmbH, Berlin/Boston

TYPESETTING Integra Software Services Pvt. Ltd., Pondicherry, India PRINTING Franz X. Stückle Druck und Verlag e.K., Ettenheim

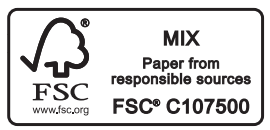





\section{Contents}

\section{Research Articles}

James Law

Conceptualizations of time in French depuis 'since, for' constructions

Hendrik De Smet, Frauke D’hoedt, Lauren Fonteyn and Kristel Van Goethem The changing functions of competing forms: Attraction and differentiation 197

Chiharu Uda Kikuta

Development of conditional imperatives in Japanese: A diachronic constructional approach -235

Jonathan Dunn

Finding variants for construction-based dialectometry: A corpus-based approach to regional CxGs -275

Simon Devylder

Diagrammatic iconicity explains asymmetries in Paamese possessive constructions -313

\section{Book Reviews}

Karin Beijering

Nicholas Evans and Honoré Watanabe (eds.). Insubordination — 349

Elitzur Dattner

Florent Perek. Argument Structure in Usage-Based Construction Grammar: Experimental and corpus-based perspectives - 363 